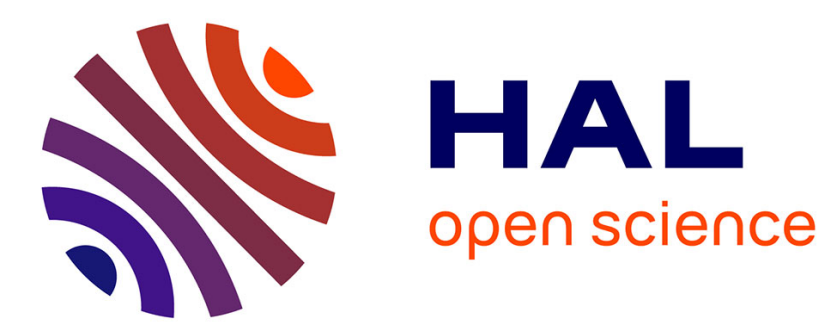

\title{
Gated communities
}

Renaud Le Goix, Chris Webster

\section{To cite this version:}

Renaud Le Goix, Chris Webster. Gated communities. Geography Compass, 2008, 118, 26 p. 10.1111/j.1749-8198.2008.00118.x . halshs-00291711

\section{HAL Id: halshs-00291711 https://shs.hal.science/halshs-00291711}

Submitted on 28 Jun 2008

HAL is a multi-disciplinary open access archive for the deposit and dissemination of scientific research documents, whether they are published or not. The documents may come from teaching and research institutions in France or abroad, or from public or private research centers.
L'archive ouverte pluridisciplinaire HAL, est destinée au dépôt et à la diffusion de documents scientifiques de niveau recherche, publiés ou non, émanant des établissements d'enseignement et de recherche français ou étrangers, des laboratoires publics ou privés. 
Le Goix, R., \& Webster, C. (2008). Gated Communities. Geography Compass [http://www.blackwellcompass.com/subject/geography/article_view?article_id=geco_articles_bp/118].

The definitive version is available at www.blackwell-synergy.com

C Geography Compass, 2008

\section{Gated communities}

5

Renaud Le Goix

Chris Webster

This paper examines the notion of gated communities and more generally, privately governed urban neighborhoods. We do this by reviewing the idea that they are an innovative builtenvironment genre that has spread globally from a diverse set of roots and influences. These include the mass growth of private urban government in the USA over the past 30 years; rising income inequalities and fear in big cities; the French Condominium law of 1804; and

15 many other locally and culturally specific features of urban history. We contrast the popular notion that gated communities are simply an American export with the idea that they have emerged in various forms for different reasons in different places. We contrast supply-side and demand-side explanations, focusing on the idea that much of their appeal comes from the club-economy dynamics that underpin them. We examine the social and systemic costs territorial outcomes - of cities made up of residential clubs, considering in particular, the issue of segregation. We conclude with a reflection on the importance of local variations in the conditions that foster or inhibit the growth of a gated community market in particular countries.

25 Keywords : Gated communities, private urban governance, institutions, segregation, clubs, complex urban systems

\section{Introduction}

Since the early 1990's a discourse has been steadily growing about a pattern of urban living that many thought to have been consigned to history: so-called gated communities or privately governed urban territory. Their rise was initially fastest in the US and Latin America, where the media and academic commentators were quick to described the 35 phenomenon in terms of security-oriented privatized urbanism. A popular critique easily followed, warning of the social fragmentation of the city; out-of control urban segregation; secession; and the end of civic order as we know it. Gated communities became for some, both symbols and symptoms of a line that is being crossed from voice-based citizenship to exit-based citizenship; from politically-organized to market-organized civic society. While the discourse on gated urbanism seemed to spread from American sources, the phenomenon itself, had its own local history in every continent and country (Carvalho, Varkki George and Anthony 1997, Caldeira 2000, Thuillier 2005): in China (Giroir 2006, Webster, Wu and Zhao 2006b), South-East Asia and Australia (Burke 2001), Europe (Glasze 2003, Billard, Chevalier and Madore 2005), Eastern Europe (Lentz 2006), South Africa (Jürgens and Landman 2006) and the Arab world (Glasze 2000, Glasze and Alkhayyal 2002a). Gating may thus be interpreted as a global trend. It is undoubtedly influenced in many ways by U.S. models but it is developed according to local political, legal and architectural traditions (Glasze, Frantz and Webster 2002b, Glasze 2005). 

compass.com/subject/geography/article_view?article_id=geco_articles_bp/118].

'Gated communities' is a euphemism. Gated estates are a sub-set of a wider genre of enclavestyle developments, better thought of as privately or collectively governed neighborhoods. By the year 2000 over $15 \%$ of the US housing stock was in so-called common interest developments - CIDs (a form of co-ownership tenure and organization) - and the number of units in these privately governed residential schemes rose from 701,000 in 1970 to 16.3 million in 1998 (McKenzie 2003; 2005; 2006b). The Community Association of America estimated in 2002 that 47 million Americans were living in 231,000 community associations and that $50 \%$ of all new homes in major cities belong to community associations (Sanchez and Lang 2005). Only a proportion - up to $30 \%$ in the region of Los Angeles for instance (Le Goix 2003) - of these private local government areas are gated. Some vote against erecting gates. Some have voted to take down gates built by developers. And of course, some (including poorer neighborhoods taking a defensive posture against lawlessness) vote to erect gates where there were none. The issue is not really the gates, it is the fragmentation of the urban governance realm into micro-territories. Some have called it the medievalisation of the modern city. Others see it as a shift back to something more natural, after a $20^{\text {th }}$ century experiment in municipal socialism: yielding back to the market certain municipal management functions.

Ed Blakely and Mary-Gail Snyder's now classic (1997) book focused academic debate and helped shape the discourse. They took a predominantly morphological view in which gated communities are simply walled and gated residential neighborhoods. Security systems, gates and around the clock surveillance meant that gating blocks public access. Gated neighborhoods therefore represented a form of urbanism where public space has been privatized. From this point of view, they differ from condominiums and secured apartment complexes because behind the gates they include shared amenities and spaces (streets, parks, sidewalks, beaches and so on), which elsewhere in modern cities, are open to everybody.

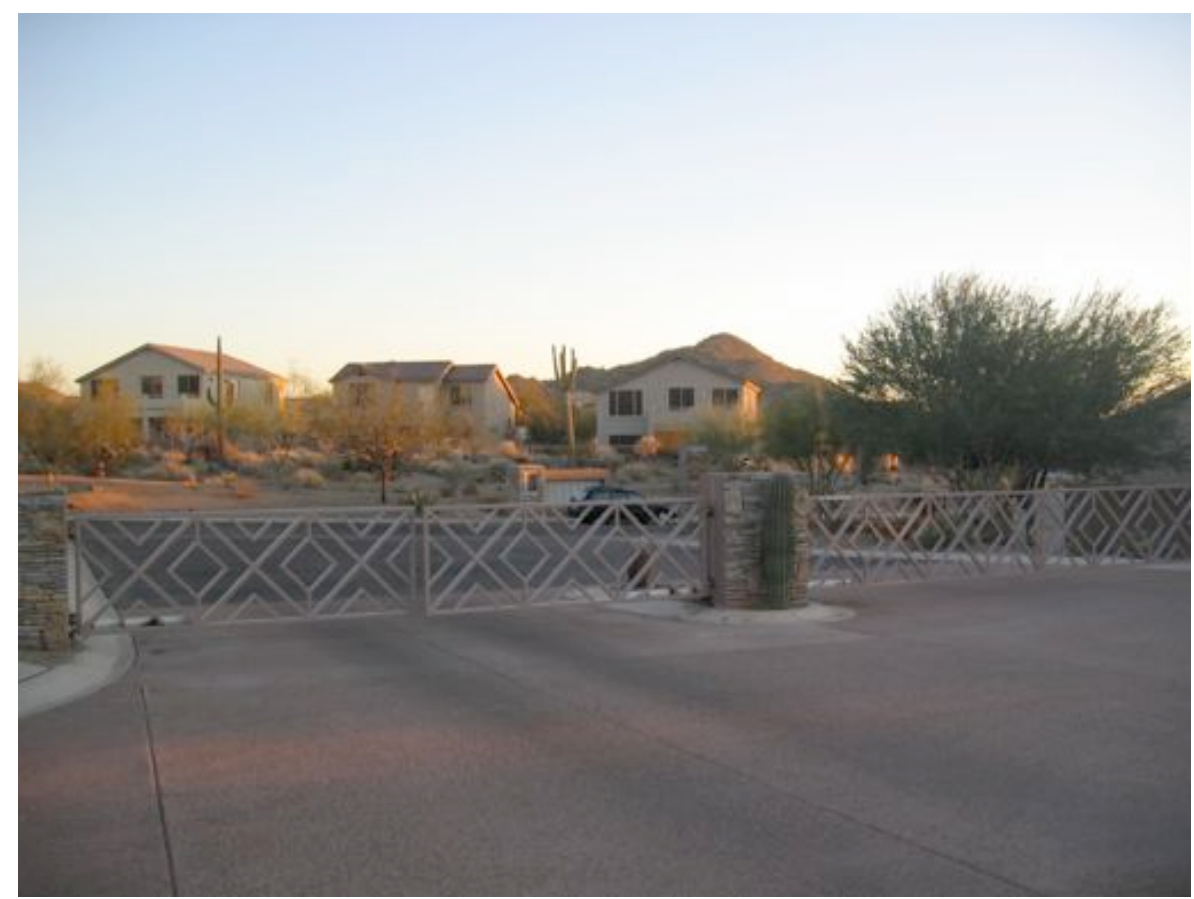

Figure 1 - A standard gated community near Pheonix (Arizona), secured by an automated gate.

(c) Le Goix, 2007 
Le Goix, R., \& Webster, C. (2008). Gated Communities. Geography Compass [http://www.blackwellcompass.com/subject/geography/article_view?article_id=geco_articles_bpl118].

Two understandings of 'gated communities' (from now on 'GCs') have therefore emerged in the academic literature. One group of scholars considers them to be a family member of a more general class that includes master-planned communities (horizontal version) and condominiums (vertical version) governed by collective tenure and incorporated organizational arrangements - Common Interest Developments; Strata-title developments in Australia and New Zealand; Community Land Trust and Commonhold Associations in the UK; and so on (McKenzie 1994, Kennedy 1995, Webster 2001, McKenzie 2003, Gordon 2004, Webster and Le Goix 2005). Important definitional considerations from this perspective therefore include the nature of ownership, governance and management. Such neighborhoods will, for example, have some kind of Property Owners Associations (POAs) employed by a governing body formed from residents tied to a common set of interests by contract. This is a very different model of urban ownership-governance-management than the conventional $20^{\text {th }}$ century city (Chen and Webster 2005).

Alternatively, others argue that it is the existence of fences, walls and security features that distinguishes gated communities as a residential form that is significantly different from non-gated enclaves (Blakely and Snyder 1997, Low 2003, Le Goix 2005, Le Goix 2007, Vesselinov, Cazessus and Falk 2007). This discourse tends to stress the alleged impact of gated enclaves on crime, segregation, property values, citizenship and related behavior.

We embrace both definitions in the discussion we develop in this paper, but most of what we have to say is focused on estates that have in place the technological and legal instruments to exclude non-residents. We speak of GCs in the more literal sense therefore. Like CIDs they are governed by homeowner associations, where elected boards oversee the common property and establish covenants, conditions, and restrictions (CC\&Rs); and managed by POAs. But unlike the wider class of privately governed neighborhoods, GCs are surrounded by a secured barrier which gives residents the right and means if they so wish, to deny access to the streets, sidewalks and neighborhood amenities within the gates.

30 The remainder of the paper is organized as follows. First, we review the discourse on the global spread of gated communities. Second, we examine the idea that GCs have emerged under diverse conditions to provide what economists call 'club goods'. Third, we consider the territorial impact of gated communities, on the sustainability of a city as a system, on segregation patterns and on other neighborhoods. We conclude by considering the local and regional institutions (laws and regulations) that make the local evolution of gated communities and other kinds of club communities path dependent. They do this by raising or lowering the attractiveness of the private urban governance model.

\section{The global spread of Gated Communities}

Gated communities have been described as a physical expression of post-industrial social changes (fragmentation, individualism, rise of communities). Relatedely, they have been viewed as representing a deep penetration in society of the ideologies of fear and security - ideologies developed by dominant economic and political actors including municipalities and the homebuilding and security industries (Davis 1990, Marcuse 1997). They are viewed as part of a postmodern trend towards the commoditization of urban public space pitched at consumers sensitized to the risks or perceived risks of modern urban life (Sorkin 1992, Dear and Flusty 1998). Commentators have recorded the phenomenon across local context: for example, in Western Europe (Raposo 2006); in post-communist Europe 
(Blinnikov, Shanin, Sobolev and Volkova 2006, Stoyanov and Frantz 2006); in the Arabian Peninsula (Glasze 2006); and in China (Wu 2005, Low 2006, Webster, et al. 2006b). The security argument drives a noticeable consensus among authors who describe the security logic as a non-negotiable requirement in contemporary urbanism and architecture. Security features and guarded booths are a level of neighborhood security above the self-defensive "armed response" placards posted on lawns, community programs of "neighborhood watch" and community policing, and defensible space design approaches (Newman 1972). At a more fundamental level, neighborhood gates simply extend the idea of the front door. It is common for commentators to move from observations about the abundance of security to a discussion of exclusion and rights (Lee and Webster 2004). A strong thesis is the link between security and fear of others - sometimes distinguished from the desire for security of person and property (Low 2001, Low 2003). In Argentina and in Brazil (Caldeira 2000), in the US or in Europe (Billard, et al. 2005), in Mexico (Low 2001), gating has been associated with a lack of confidence in the public security enforcement. An early theorization of gated streets as defensible spaces was developed by Newman (1972) and his Institute for Community Design Analysis. His studies have been widely publicized and incorporated in public policies through urban design guidelines aimed at preventing crime (Newman 1996). Newman makes an apology for gating as a device that prevents urban decay by giving social control over the environment to residents. This includes the erection of street barriers in retrofitted residential neighborhoods as a way of reintroducing public safety, and controlling gang activities. Retrofitted neighborhood gating occurs in low-income and public housing subdivisions, for example, Mar Vista Gardens and Imperial Courts in Los Angeles South Central (Leavitt and Loukaitou-Sideris 1994); as well as in higher income areas of insecure cities, for instance in South Africa (Jürgens, et al. 2006, Landman 2006).

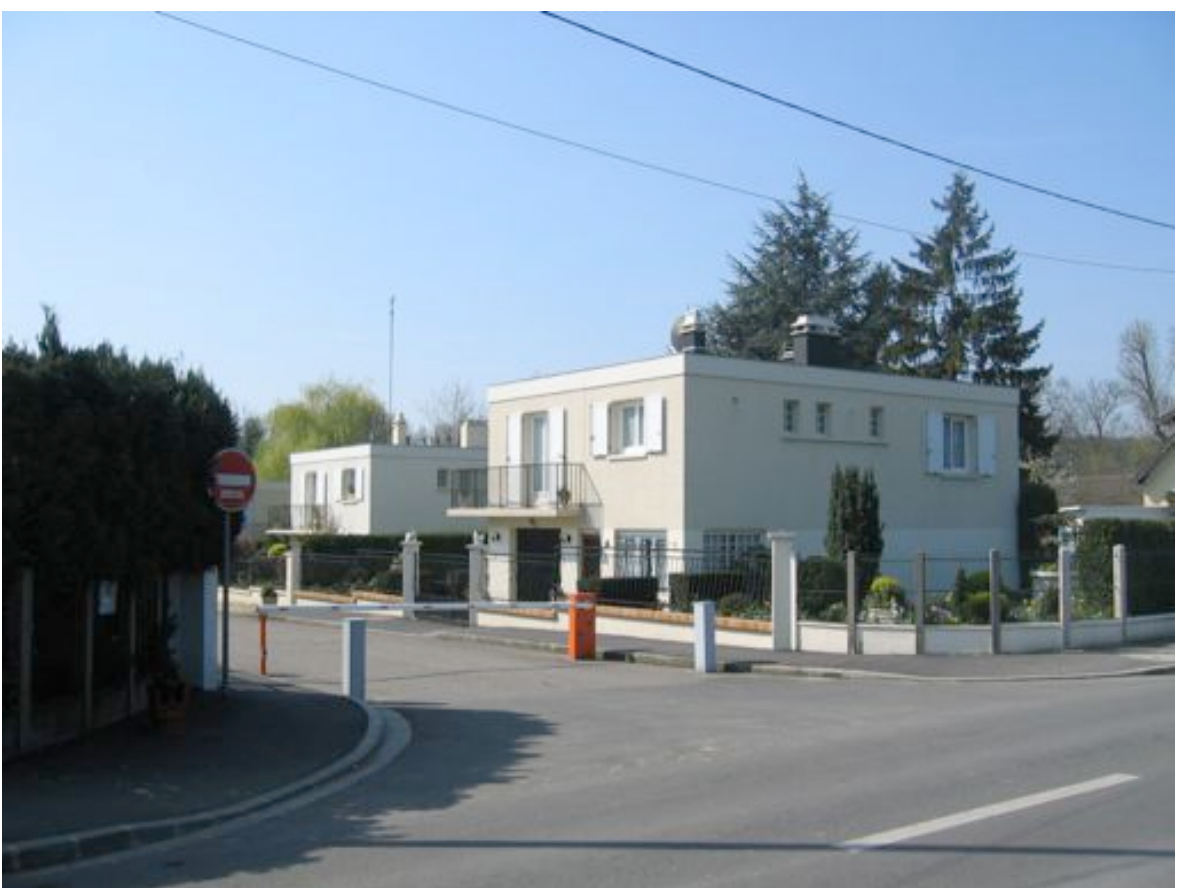

Figure 2 - A retrofitted closed neighborhood near Paris (93 - Seine-Saint-Denis) () Le Goix, 2006

Beyond the specific emphasis on fear, a second type of argument depicts gated communities as a symptom of urban pathology focusing on social exclusion issues and the retreat of the so-called public realm. The decline of open-access public space in cities is 

compass.com/subject/geography/article_view?article_id=geco_articles_bpl118].

viewed as being detrimental to the poorest social classes and gating thus tends to be associated with an increase of social segregation (Blakely, et al. 1997, Caldeira 2000, Glasze, et al. 2002b, Thuillier 2005). The most publicized occurrences of this discourse stress the effects of gated neighborhoods on entire communities, especially their spillover effects on neighboring areas. In some instances, citizen groups, such as those documented in the 1994 Citizen's Against Gated Enclaves (CAGE) vs. Whitley Heights Civic Association case, have pushed to ban the gating of public streets (Kennedy 1995), arguing that gates would prevent the free access to a public property. The argument is made - in legal cases such as this and in public and academic debates - even though it is the residents within the gates who finance their own street maintenance. In other words, ownership issues are frequently subjugated to arguments pitched at morally higher ground - foremost of which is the right to roam the city. There is an obvious parallel to the long rehearsed arguments about the right to roam the countryside (Lee and Webster 2006, Webster 2007). Some governments have tried to regulate or ban the proliferation of gated enclaves on the grounds of their exclusionary nature (Reville and Wilson 2000, Grant 2005).We return to the issue of segregation later in the paper.

Earlier commentators on gating tended to conflate an analysis of these alleged evils with the analysis of innovation diffusion (though few if any used that term). The conflation was no doubt partly due to the dominant negative view among critical urban theorists of globalization - especially of American consumerist values. However, as the debate has matured and broadened, the idea that gated communities have spread from America to the rest of the world has been challenged by the idea of local emergence (Webster and Glasze 2006a). While acknowledging that there are undoubtedly processes of market extension and cultural exportation going on, some authors have also stressed the local specificity of gated development in specific national contexts, for example Latin America's rich history and modern culture in gating (Thuillier 2005). In Latin America, many appeared in the 1970s as a middle- and upper-income exodus to suburban areas where lower-income groups had been settling since the 1940s (Caldeira, 2000). In those circumstances, gates were used to maintain a physical separation between classes when physical distances between rich and poor are short (Carvalho, et al. 1997). Exploring the dual idea of spread and emergence in Lebanon, Glasze notes the similarity between some gated compounds and American developments, and also describes the links between US developments and Lebanese investors (Glasze 2000). Gating became popular in the Lebanon during the insecurity of the civil war and was for many a necessity in the face of public government unable to provide not only personal and 35 property security but security of the services and goods that make up modern urban life. So there are particular reasons intrinsic to particular countries and regions that provide the necessary dynamic for gated communities to emerge - whether through direct implant of foreign ideas by foreign real estate firms, more distanced and subtle copying, or local experimentation and invention.

40 The domination of the gated genre in South Africa clearly has very specific local causes. It has been linked to post-apartheid postures, unilaterally by residents (Durington 2006), by developers or by more complex coalitions of local actors (developers, municipalities). The spread of enclosed enclaves (street closures and walls) is not only due to developers, but also to a strategy coordinated by local and national authorities and by very pro-active residents associations. This has given rise to the extraordinary phenomenon of mass road closures, in which streets belonging to public governments are unilaterally enclosed by a boom gate and guard house and the enclave permitted to incorporate as an owners association ("Section 21 Company") (Landman 2006). 


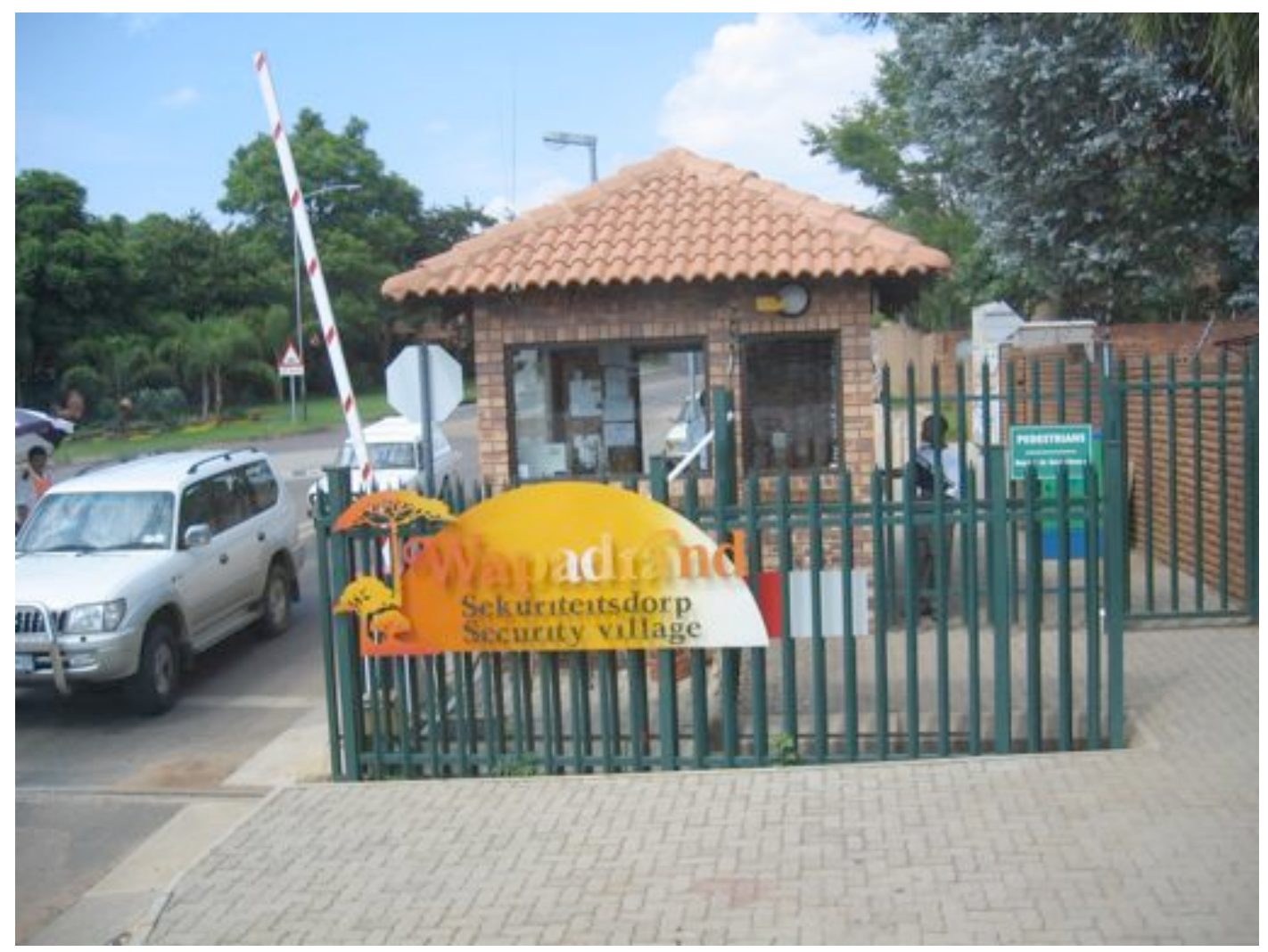

Figure 3 - Gated streets in South Africa (public streets managed by "Section 21 companies") (c) Le Goix, 2006

5 The shift from 'spread' to 'emergence' as an underlying explanation naturally leads to the study of locally specific antecedents to the modern gated city. Gated cities have a long history. Socially and physically defined urban enclaves are as old as cities themselves. Private urban governance emerged in $19^{\text {th }}$ century industrial European cities such as London and Paris, in which the new industrial bourgeoisie sought in privately operated and enclosed suburban neighborhoods, a quiet retreat from the busy city center (Foldvary 1994, McKenzie 1994). Le Parc de Montretout, in Saint-Cloud, France, developed in 1832, probably being the first of its kind (Degoutin 2004). In the US, the spread of gated communities has roots in that country's long standing ideology of suburban development. One early thread of influence is the romantic suburban utopias and utopian-influenced projects. Haskell's Llewellyn Park was probably the first modern gated community built in the U.S. It has continuously operated a gatehouse and a private police force since 1854 and introduced private governance of shared amenities based on deed restrictive covenants that protected the stability and homogeneity of the neighborhood (Jackson 1985). A second thread links America's modern gated communities to the historical processes that brought Common Interest Developments (CIDs) and exclusionary restrictive covenants laws from Europe to the U.S. McKenzie (1994) explores the long European history of restrictive covenants and residential associations (observable since 1743 in London). The first homeowners association per se was created in the US in 1844 in Boston's Louisburg Square. Llewellyn Park and Roland Park (1891) were the first large privately owned and operated luxury subdivisions, yielding exclusive neighborhoods. They established consumer and real estate developer expectations and legal and organizational approaches that helped shape contemporary private urban governance in the U.S. McKenzie writes "to maintain the private parks, lakes and other amenities of the subdivisions, developers created provisions for common ownership of the land by all residents and private taxation of the owners. To ensure that the land would not be put to other 
Le Goix, R., \& Webster, C. (2008). Gated Communities. Geography Compass [http://www.blackwellcompass.com/subject/geography/article_view?article_id=geco_articles_bp/118].

uses by subsequent owners, developers attached 'restrictive covenants' to the deeds." (McKenzie, 1994, 9). In the first half of the XXth century, this kind of high-end subdivision became quite common (Mission Hills, Missouri in 1914, Kansas City Country Club District in 1930s, and Radburn in 1928). Along with landscaping and architectural requirements, the idea of social preferences as a commoditized attribute has become common in CIDs. Exclusive lifestyle developments became common by the turn of the 1960-70s, designed as massconsumption real estate developments, financed by large corporations attracted by potential profits and backed by the Government through the Department of Housing and Urban Development (McKenzie, 1994).

Historical investigation of gated enclaves has produced a rich international comparative analysis that reveals the importance of local focus on the condition of appearance of gated developments. In China, gated communities are nothing new, but simply a continuation of enclosed work-unit territories (dan wei) and the walled low-rise courtyard houses and

15 residential neighborhoods found traditionally in villages and urban neighborhoods (Low 2006, Webster, et al. 2006a). In the US, the mass phenomenon of middle-class gated communities might be traced back to the 1960s. Comparing these two countries, Low (2006) notes "yet both regions have fragmenting urban development. Further, the expansion of private communities is supported by neoliberal states retreating from the provision of housing 20 and social goods as well as by Chinese cities where state control of housing is still strong." (Low, 2006). In fact, China's strong control over land and housing has enabled municipal governments to engineer a faster rate of retreat to private (collective) territorial government than has been possible in any other country. This is partly because of the strong legacy of collective organization left by the central-planning era. We return to this at the conclusion of

25 this paper. The case of China's fragmented cities brings us neatly to the idea of residential clubs.

\section{Residential clubs and the appeal of Private Urban Governance}

The economic theory of clubs (after Nobel Economic Laureate James Buchanan) challenges the neo-classical notion of public goods. In reality, Buchanan noted, few goods are truly public in the sense that any number of people can consume them without reducing the benefit enjoyed by others. Most jointly-consumed goods and services are consumed by groups smaller than infinity. A club, in economics, is a method of supplying jointly consumed goods efficiently on the basis of controlled membership and fee. It was applied initially to privately 35 organized arrangements - entrepreneurial clubs - but is readily extendible to publicly or nonprofit organized arrangements. It gives rise to the idea of club goods - in contradistinction to public goods and to club realm as opposed to public realm (Webster 2002). Gated communities can be understood to be territorial clubs, the sole purpose of which is to supply club goods. This line of argument sees GCs as neither public nor private spaces. They are club spaces - spaces governed by 'small publics'. Compared to general purpose municipal governments, they are alleged to be more efficient organizations for allocating scarce and congestible neighborhood goods for a number of reasons. They provide greater choice for one thing, and residents can vote with their feet to choose the bundle of shared goods and services they prefer at a price they think reasonable (assuming there is sufficient competition among developers and between established club communities to avoid monopoly practices). This leads to a comparison between the club community market and the imaginary spatial economy of geographical economist Charles Tiebout (1956). This is more efficient than public government in the sense that there are fewer unrealized gains from trade in the urban land market. In other words, more people have their specific preferences (for civic goods and 

compass.com/subject/geography/article_view?article_id=geco_articles_bpl118].

services and for type of neighbor and neighborhood) met (Tiebout 1956). The exclusionary mechanism of 'membership' means that there is a more precise relationship between payment and benefit received than there is in publicly managed neighborhoods. Significant investments made by POAs are capitalized in land rent. Not only do owners have an incentive to invest in their local environments, but also they can recover investment costs from rents (Foldvary 1994).

In some ways this is an economic counterpart to Newman's architectural-behavioral analysis. Newman's studies for the U.S. Department of Housing and Urban Development are often cited as evidence that gated enclaves are politically and financially sustainable institutions. The sustainability is ensured by the existence of the HOA, which has three basic characteristics. Elected boards act as neighborhood decision makers; contracts govern resident behavior (through CC\&Rs); and monthly fees finance local amenities and services (McKenzie, 1994). By interpreting GCs as mechanisms for supplying environments, security 15 and other goods and services that are neither private nor public goods, the club economy model moves beyond polarized discussion about access to public goods and the privatization of space. It allows a more nuanced and specific debate about the roles of markets and governments in shaping, governing and managing the city. An example is the comparative analysis of the institutions (laws) necessary for a market in GCs to form in the first place; those necessary to govern such markets in the interests of third parties (those not living inside the gates); and those needed to protect the interests of the various transacting parties in the club market (residents, developers, land owners, municipality, HOA, property management company - each of which needs legal protection from opportunist and exploitative action by the others).

Regardless of local traditions and national legal contexts, there are three main organizational types of private residential neighborhoods, differentiated by the way property rights over shared spaces and facilities and over exclusively used housing units are assigned (McKenzie 1994, Glasze 2005). In condominiums, in addition to individual property of the housing units, the owners hold title to an undivided interest in the common property of streets, open spaces, amenities and so on. An individual's share of the common interest is related to his/her share of exclusive property owned (number of units or area) and the shared interest assets are governed by a POA run by an elected board of directors. In stock co-operatives, individuals purchase a share in an entire residential complex, but the co-op owns both the 35 exclusively owned housing units and the subsequent shared amenities. The share gives the member voting rights at the co-op assembly. In corporations, the common spaces and facilities are the property of an incorporated body set up specifically for that purpose - the corporation. In these cases, a covenant is attached to the deed of a residential lot making the owner a shareholder in the corporation with voting rights according to the amount of the share. This type is often called a homeowner association. When shareholders are not identical to the people owning or renting the housing units, this type is sometimes referred to as 'proprietary neighborhoods' (Glasze 2005).

These devices are also used to govern non-residential (commercial) neighborhoods. 45 However, the more common device here is the multi-tenant property, the classic example of which is the shopping mall. The owner retains freehold possession of the individual shop units let out to retailers as well as to the common facilities. Investment in the latter is recovered through rents of short term leases. This is less applicable in residential neighborhoods because of the popularity in most cultures of home-owning. On the other hand, 
Le Goix, R., \& Webster, C. (2008). Gated Communities. Geography Compass [http://www.blackwellcompass.com/subject/geography/article_view?article_id=geco_articles_bp/118].

there has been some experimentation with Home Owner Association, condominium and other local adaptations of co-ownership organization and tenure to govern the joint-consumption problems of commercial neighborhoods (Chen, et al. 2005, Chen and Webster 2006)

5 These institutions have emerged to reduce the costs of individuals cooperating within urban neighborhoods. They are legal devices that solve some of the spill-over problems endemic in cities by internalizing them within a single organizational and legal entity. In the economics literature this is referred to as unitization. They oil the wheels of contractually governed cities. The institutions are not the driver of gating or other forms of privatization, however. An efficiency explanation for the growth of 'cities of clubs' must ultimately be made in terms of advantages gained and efficiency must be defined in terms of particular objectives and means different things for different groups.

At least three efficiency arguments are important in understanding urban fragmentation from 15 a club-theoretic perspective. Firstly, compared to municipal-scale governance, as we have already noted, micro-scale collective decision making theoretically leads to a closer fit between the demand for and supply of local collective goods and services. Consensual decision making creates a certain level of social homogeneity: through invention and trial and error, developers discover how to design GCs with levels and mixes of services and amenities that fit the preferences of different groups. For those able to participate in the club economy, this is likely to be a preferable model of the city to one in which the quantity, mix and quality of neighborhood goods and services is determined by general purpose city-wide government, often with a strongly redistributive agenda.

25 Secondly, most local public goods are consumed by sub-sets of the wider public. If they are open to an infinite number of users they are likely to become congested and degraded. They are therefore better supplied as club goods, where the number of members and the quantity and quality of the facilities are determined by design and managed accordingly (Webster 2003, Webster and Lai 2003). Generalizing from this, from a sustainability perspective, scarce resources are better enclosed than unenclosed. Open access resources suffer from overuse (Hardin 1968). Well-preserved open access resources incur very high costs. Indeed, a tragedy of the urban commons is played out in the public spaces, services, and infrastructure of cities throughout the world (Le Goix and Webster 2006). Following Hardin, resources that are governed by shared use-rights tend to deplete through unrestrained competition. As this 35 happens, there is a demand for the reassignment of rights to protect against complete resource dissipation (Barzel 1997, Webster, et al. 2003), and gated communities are an example of this.

Thirdly, reorganizing a public city into a city of clubs can raise the total amount of revenue going into the management of the urban environment since people are clearly willing to submit to a double taxation regime (municipal government taxes plus GC fees). The flip side of this is that local governments can save money by off-loading responsibilities to HOAs (McKenzie, 1994).

45 Seen in this light, the search for security is only a very partial explanation of the spread of GCs. Gated neighborhoods have given home-buyers greater choice, lower risk, lower search costs and greater investment security. They have also enabled public authorities to manage growth with greater fiscal sustainability. In fact, gating is highly correlated with the fiscal gaps increasingly experienced by local government bodies worldwide. Indeed, the diffusion 
of gated communities in a metropolitan area is often related to suburban growth, in many countries an endemic anti-fiscal posture leading to municipal fragmentation and a Tibeoutian world of small competitive local governments. Urban sprawl in the U.S. and in many developing countries continues to generate demand for new infrastructure but political, legal and technological limits on the amount of property tax that can be collected lead to undersupply. As a result, gated communities, which bring wealthy taxpayers at minimal cost, have become the perfect cash cow for local municipalities (McKenzie 1994, Le Goix 2006). In turn, they contribute to territorial fragmentation.

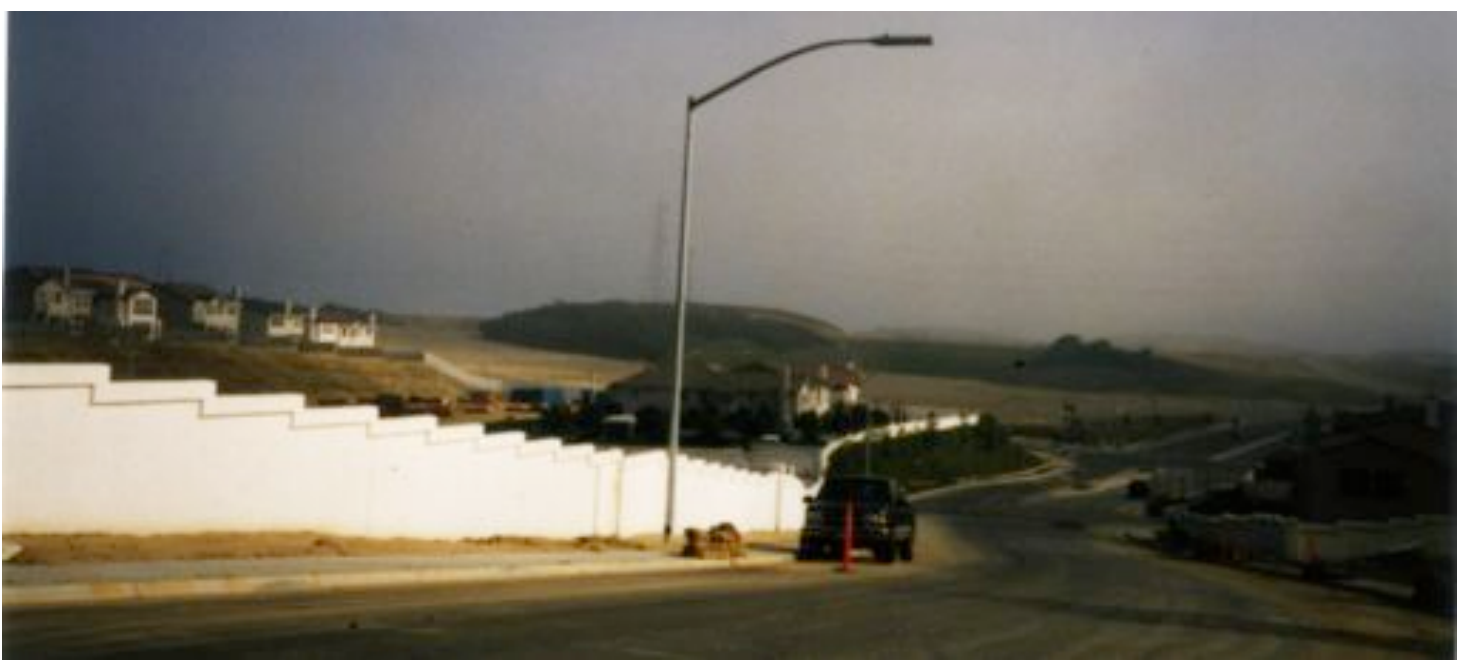

Figure 4 - Walls as generic patterns in suburban landscapes.

In Carmel Valley (San Diego, USA), former farm and ranch lots are being developped. Gated communities and private urban governance (Home Owners Association) become prevailing structures in suburban areas. Market is driven by demand and by fiscal local interests. (@ Le Goix, 2000)

There is some discussion in the literature about which of the various explanations or drivers is the most important. Is it revenue-maximizing local authorities; discerning home-owners; or innovative developers? At one level it is possible to make comments about demand and supply-side explanations. For example, it is quite clear in places of severe fiscal deficit that local governments can drive the development of a mature and competitive GC market. This is a supply side explanation. So is the idea that international real estate companies transfer the gated genre from one continent to another and that enterprising domestic developers copy and adapt, diversifying the product and finding ways of making acceptable to new markets taking it down market, for example. Supply-side explanations in some ways seem more powerful than demand side analysis. This is possibly because the activities of sellers are by nature more obvious than the activities of buyers in shaping the product. It is easy to see the information flowing from seller to buyer (the adverts in Chinese newspapers offering a corner of California, Tuscany or the English home counties in suburban Beijing, for example). The information flowing from buyers to the sellers is less visible. But it flows nevertheless. The first developer to build an Orange County Beijing estate would be the last if the project did not sell. Developers and investors only outlay capital if they expect a certain rate of return. Those rates of return are carefully measured and based largely on anticipated market trends anticipations about customer preferences. The truth is that buyers and sellers symbiotically discover together what products are successful in yielding mutual benefits - profit for the producers and consumer surplus (benefits, enjoyment, value for money etc) for consumers. Both need each other to make gains. Their relative power changes according to market conditions and by government laws and policies. In a buyers' market, for example the over- 

compass.com/subject/geography/article_view?article_id=geco_articles_bpl118].

supply of condominiums in Asian cities after the 1997 financial crash, sellers invest what would otherwise be profit in searching for buyers. They buy bigger and longer running adverts and they make special offers and add extras. In a sellers' market such as the Asian condo market in the years leading up to 1997, buyers assume more of the costs of searching for a property and developers advertise less and give away fewer inducements.

There are other things that can be said about the buyer-seller relationship. In general, the industry generates a more comfortable margin when selling houses with a lot of services for which the added value is higher (by comparison, the financial margins from building a house can be low). So in housing boom times, there is likely to be supplier-led imbalance in favour of higher-end GCs. In down-turns, a more balanced spread of consumer preferences is likely to guide supplier behavior (many condo schemes in South East Asia were re-packaged for down-market customers after the 1997 crash). The rapid spread of GCs over the past 30 years has coincided with two periods of very rapid house price rises for most of the world - during

15 which developers of GCs have generally had the stronger hand in sales. They have been able to assume more about consumer wants and to get away with it more when they have been wrong. In immature property markets where GCs are spreading, such as the transitional economies of Eastern Europe, China and Russia, there is a very real sense in which developers have been teaching consumers what to want - educating the burgeoning middle classes in the art of home-ownership. But it should never be thought that this is an entirely one-way process. GCs products diversification is relentless in these ultra competitive emergent markets - particularly, as in the case of China, where competition between revenuemaximizing local governments lowers regulatory barriers. As with malls throughout the rapidly developing world in the 1980s, new GCs innovations seem to come onto the market 25 every month in Chinese cities. Those that succeed in meeting customer demand thrive, set the standards for subsequent developments and set benchmarks against which further innovation is gauged. Innovations that fail to meet customer demands - including early-comers in the local GC product life-cycle - go down market. Few projects fail in these hot-house conditions but many become locations of second choice. Buyers move on to better-appointed GCs. 30 Developers and investors may lose out but lower income households waiting to buy into the gated lifestyle often benefit.

One more aspect of the buyer-seller relationship that should be noted concerns lawyers and the relative lack of buyer knowledge about private urban governance. With most residents 35 lacking specialized knowledge about the legal details of GC contracts, information asymmetries abound and there is plenty of scope for buyers to lose out in negotiations with developers. This is worse in sellers' markets for the reasons already discussed and it is worse at the early stages of product life cycle - when the contractual and governmental problems likely to arise from GCs in a particular local context are little known. In 1998 US GC lawyer Evan McKenzie was worried that minimal state regulation, "has created a situation in which private contracts are being used to structure relationships involving public values, institutions, consequences and issues" (McKenzie, 1998, p. 399). A decade later, there is a lot more state regulation, which has developed as society has discovered by experience the ways in which GC markets can fail. Ironically, however, the more complete the state legislation (McKenzie 2006a) and the more organized the GC market becomes, the longer and more complex are the contracts. This will always tend to put sellers at an advantage over the individual buyer. The way to guard against this, as in the packaged tour industry (GC is a packaged neighborhood industry) is to keep competition alive. Another irony is that this is more likely to happen if there are less regulation. 
Le Goix, R., \& Webster, C. (2008). Gated Communities. Geography Compass [http://www.blackwellcompass.com/subject/geography/article_view?article_id=geco_articles_bp/118].

\section{Territorial Outcomes of Gating}

The most compelling evidence in favor of the efficiency argument for (or explanation of) GCs is the sheer size of the market. However imbalanced or asymmetric the information flows might be, hundreds of millions of residents worldwide have, as economists say, revealed their preferences for gating and other forms of private neighborhoods. This says nothing, however, about the social efficiency of GCs and here the debate rightfully rages on. The jury is still out on nearly all alleged systemic problems resulting from GCs and more empirical studies are needed. Some of the most noticeable territorial outcomes of gating can be summarized as follows.

First, travel behavior throughout the urban network can change. Traffic can be diverted by gates and walls and pedestrian routes lengthened (Burke 2001). Second, gates frequently contribute to a decrease in burglaries and larcenies (Atlas and Leblanc 1994), but divert crime to other non-gated communities (Helsley and Strange 1999). Specific evidence of these diversionary spill-over effects is scarce, but they do not really need to be evidenced. Crime and traffic barred from one place is bound to divert unless something else happens to reduce the total volumes. Possibly more serious than the diversion of actual crime is the cranking-up of the fear of crime - a kind of spill over. This is not a general problem of gating, as some commentators like to think, but it is a huge problem in South Africa and probably in other very insecure places too. The rapid diffusion of security features in some South African cities - signing up to rapid armed response services, gating, electric wires, CCTV and double fencing - by copying neighbors can only be described as a systemic breakdown of crisis proportions. It is a net diseconomy pushing aggregate security expenditures way beyond levels commensurate with real crime risk. This is not a peculiar spill over effect of GCs but in the particular tragic mix of circumstances in South Africa, they are caught up in it.

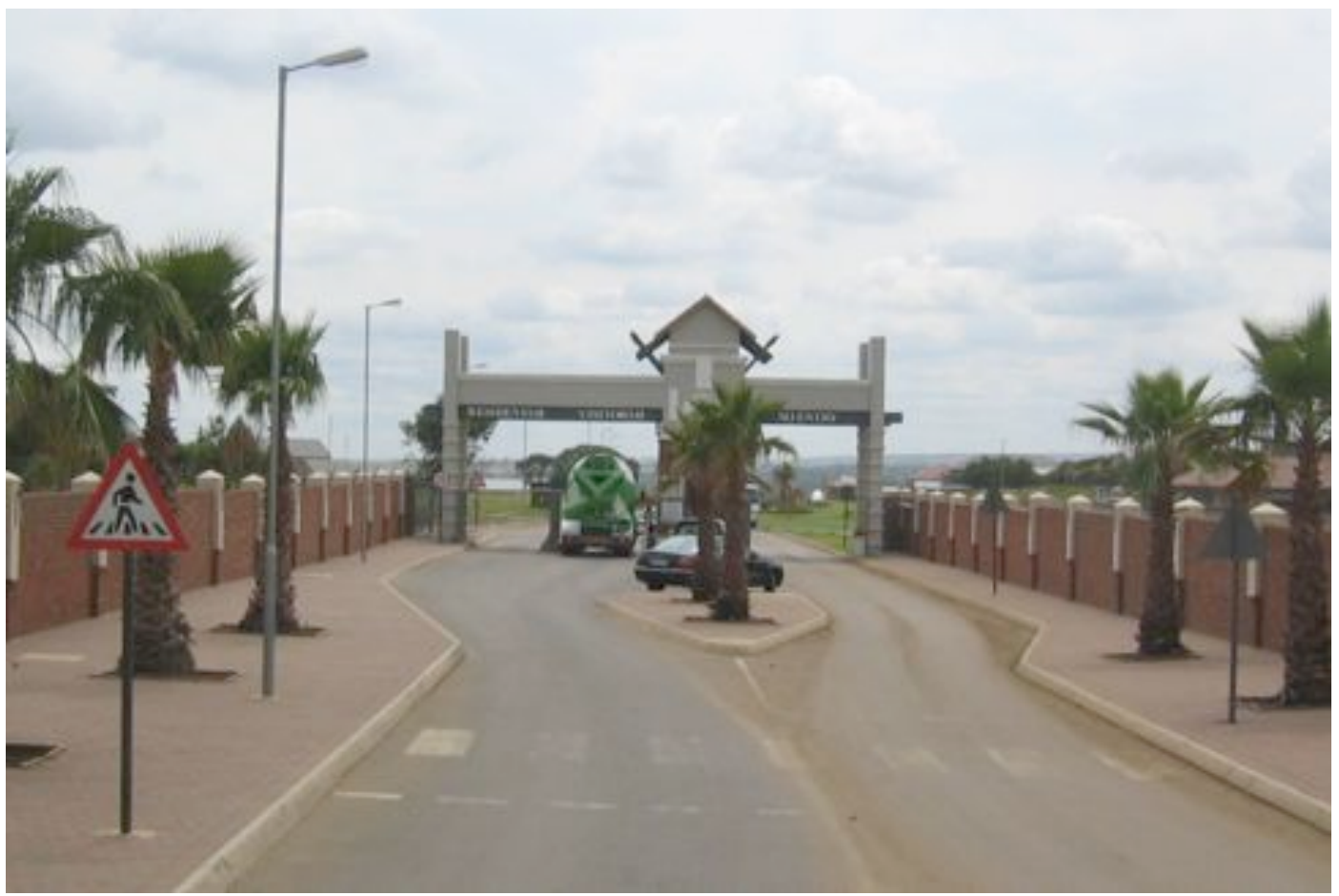


Third, GCs produce noticeable positive effects on property values within the gates (Bible and Hsieh 2001, Lacour-Little and Malpezzi 2001) but there is some evidence that the price premium is sometimes detrimental to properties in non-gated development nearby a gated community (Le Goix 2002). This is an interesting empirical question that needs further investigation. On the one hand, price rises would normally have positive knock-on effects on substitute properties. A high-end GC in a low income area of a developing city, for example, will boost local home values. If there are other middle income housing areas nearby, a GC of sufficient prominence might have an enhancing effect. On the other hand, if GCs are of sufficient size that they effectively introduce a layer of superior housing above the existing housing stock - then the existing housing might be marked down. This is more likely to happen in times of excess supply.

15 Karina Landman proposed an analytical framework for monitoring the spillover effects of CGs in terms of negative feedback loops as they affect urban planning, local financial stability, the traffic network and security dynamics (Landman 2006). But the risk might actually be greater inside the walls. To live up to their sustainability promise, GCs need to be founded on a financial model that takes account of rising costs due to the obsolescence of infrastructures and amenities managed by the property owners association. The liberal hypothesis assumes that operating costs of private governance are paid for by the increase of property values and that this is recoverable through fees, sales and rents. This is confirmed in some places, for instance in South Africa, where gated community property values are usually higher than in regular neighborhoods (Altini and Akindele 2005). But long term studies 25 conducted on legacy large enclaves in the US, have demonstrated that failure of property owners associations occurs when costs are raising above a sustainable level compared to rapidly decreasing property values (Le Goix 2007). In principle, this is addressed by government legislation requiring adequate re-investment funds, but there will undoubtedly be many failures in many countries before legislation has its effect - if it does. It may be that the private costs of private government (as opposed to the social costs) are its downfall. More likely, as the true private and public costs become known, legislation will adjust and a workable balance and distribution of liabilities will emerge between private and local governments and between the different interested parties.

35 Finally in this section, it is worth reflecting in a little more detail how the legal structuring of private urban governance sustains the neighborhood club economy - specifically by producing homogeneous enclaves but in so doing poses risks to the harmony or wider urban society. CIDs explicitly aim to protect property values through various design policies and the application of Covenants, Conditions and Restrictions (CC\&Rs). Throughout the first half of the 20th century, the application of restrictive covenants to residential neighborhoods was an instrument for selecting residents, especially on the basis of race (McKenzie 1994, FoxGotham 2000). Both developers and governments backed such discrimination. Since the US Supreme Court declared residential segregation illegal in 1948, however, restrictive covenants and POA membership have relied on age limitation (for retirement communities owners must 45 be older than 55) and on required membership (e.g. in cooperative housing or country-club), membership being subject to the approval of the board of directors (Kennedy 1995). Although no reference to race or color can be made during the membership application process, the issuance of membership is discretionary, based on the principle that any club may regulate its membership (McKenzie, 1994, p. 76), as long as the criteria for selecting prospective buyers 
remain reasonable. So far, sociability and congeniality have been considered reasonable criteria by the US courts (Brower 1992). Property prices, lifestyle accoutrements and labeling and the characteristics of existing residents all serve as filters in the homogenization process. Indeed, some covenants and regulations strictly derive from the gating and enclosure of a neighborhood and this may have subtle effects on homogeneous club formation. For instance, in many GCs, residents have to send a list of guests to the POA when organizing a party a few days in advance for gate access. Such surveillance is a highly selective process and is likely to attract a certain kind of homebuyer. According to Brower (1992) and Kennedy (1995), many court cases and legal restrictions foster the social selection process. The activity of private militia within a GC are not subject to the $4^{\text {th }}$ amendment of the US Constitution (1921 Burdeau v. McDowell 256 US 465), for example. Streets, roads and parks in GCs are not legally considered to be public spaces, and therefore certain constitutional rights (particularly freedom of speech) cannot be guaranteed or are subject to POA regulation (1997 United States v. Francouer ; 1982 Laguna Publishing vs. Golden Rain Foundation). For these and

15 similar reasons, some view the growth of privately regulated neighborhood life to pose a risk to certain central features of modern civic society. One response to the anxiety is that higher level governments have thus far proven themselves vigilant in making laws to mitigate illeffects of the private governance market. On the other hand, we are reminded of Thomas Schelling's famous model of social segregation: in a city populated by individuals with a weak preference for living in mixed communities (they are happy to live in neighborhoods with $49 \%$ 'others', for example), spontaneous knock-on effects in response to a small number of randomly moving individuals quickly divides the whole city into sharply segregated enclaves. This leads us to our penultimate section where we review the segregation issue in more detail.

\section{Segregation}

Resident filtering occurs when restrictive covenants and property values limit potential candidates for homeownership. The result is neighborhood homogenization by wealth, age, race and status. Whether the homogenizing effects of privately governed communities are greater than those of conventional neighborhoods is an empirical question, the answer to which depends on local context. Market-driven cities tend to filter people by income or race into well-defined areas. Micro regulation through private covenants and exclusionary zoning is likely to amplify segregation tendencies.

35 Linking gating with residential segregation is a consistent theme in the academic literature (Blakely, et al. 1997, Caldeira 2000, Le Goix 2003, Gordon 2004, Atkinson and Blandy 2005, Le Goix 2005, Manzi and Smith-Bowers 2005, Blandy, Dixon, Dupuis and Parsons 2006, Vesselinov, et al. 2007). There is also a consistent link between fear of others, fear of crime, gated communities and segregation. The latter argument has been most fully developed in the south African case, where GCs are commonly viewed as a continuation of a form of apartheid (Lemanski 2004).

There are other scholars, however, who emphasize the integrative effects of gated communities. Manzi and Smith-Bowers (2005) present two London case studies where upper scale GCs are constructed in lower income areas, arguing that without gating these communities would never have ended up as close neighbors. Salcedo and Torres (2004) conducted research on a high-income gated community built next to a long-established poor squatter community on the outskirts of Santiago, Chile. They found that lower-income residents welcomed their new neighbors as sources of employment. The new development 

compass.com/subject/geography/article_view?article_id=geco_articles_bpl118].

also brought trunk water, sewerage and other utilities to the location; services that the squatters had lobbied for unsuccessfully for years. In turn, the wealthier residents valued their poorer neighbors who supplied essential trades and services. Surprisingly, this ethnographic study documented that inter-community relations were much healthier than the intra-gated community relations (gated residents did not always speak well of each other but spoke well of their poorer neighbors) (Salcedo and Torres 2004). Contrastingly, a study by Low (2003) showed that incomers to a GC were concerned about "ethnic change" in the neighborhoods they had moved from and had covert concerns about social order, social control and generally expressed xenophobic and ethnocentric views. The findings of these two studies are not necessarily at odds however. Concerns about ethnic balance in neighborhoods previously lived in are very likely to be detected in many middle and higher income honey-pot locations. The idea that cities spontaneously segregate is well established in theory and empirical studies - as we noted with our earlier reference to Schelling. The interesting question posed when new social geographies are established through GC-based gentrification - and the challenge to established understanding of segregation - is how well gated communities and surrounding neighborhoods, especially of lower income, become functionally integrated and how this changes intergroup attitudes and wider complex systemic effects.

This question is all the richer and more complex because, as in Los Angeles, in many places gated communities are available within every market segment. There is a diversity in the gated community phenomenon that does not always come out in the literature, as Sanchez and Lang document $(2003,2005)$ using a nationwide sample of census data. Contrary to popular conceptions, gated communities are not solely composed of wealthy, white and retired residents; buyers of various classes seek to purchase homes in clubbed neighborhoods. A

252003 study of California showed that while most GC are located within upper- or middleclass white areas, 20\% are located within middle- and lower-income Asian or Hispanic neighborhoods, which proliferate in the northern parts of Orange County and San Fernando Valley (Le Goix 2003, 2002). In a follow-up study, data from the 2000 US Census shows that gating seems to increase social and economic segregation (Le Goix 2005). The combined effects of property values and community socio-economic structure create significantly higher levels of segregation between gated developments' block groups and abutting areas than in non-gated neighborhoods. It also found that gated communities are more likely to be segregated by age from adjacent areas than other neighborhoods. Indeed, gated developments attract middle-aged people and seniors, who desire to protect the lifetime investment 35 capitalized in their home. The effect of race or ethnicity in the study are particularly interesting. Gated communities in LA do not generally create 'worlds apart'. All else being equal, they are less likely to be segregated by race or ethnicity than other regions of the city (Le Goix 2003; 2005).

40 The way in which gated communities differentiate themselves from abutting neighborhoods is a complex issue therefore. Although developers try to assure that prospective buyers will feel comfortable in the broader neighborhood, they also provide them with carefully-pitched elements offering snob value and status exhibition. Following these practices, social patterns inside gated communities might be expected to be generally consistent with abutting 45 communities. However, where development sites are in short supply, this may not be possible, and where a gated development is large enough, the area effect may not act as a disincentive to buyers. In addition, it is more likely that a large, high-end CID development would locate near lower-income neighbors than upper-class single-family homes. Municipalities often encourage these gentrifying actions, which increase the local tax base. 
Consequently, gated developments have a powerful ability to sort people into preferencerelated groups and to intensify income-related and status differentiation. One of the intriguing features of gated-style urban development is that the club factor changes the spatial scale of the filter. Gentrification, mixing and separation processes will be shaped by the scale at which groups act collectively. Vernon Henderson observed in the 1970s that the well organized development industry in the US helped keep cities from growing too large: it was capable of building whole suburban communities above the size threshold necessary to attract peoples from cities that were growing beyond an optimal size. In the same way, an organized club neighborhood industry is capable of building 'safe' neighborhoods above the threshold that will attract higher income residents into lower income areas. This is all the more so when the developments are physically gated. In sum, the evidence on the segregation effects of gated communities is mixed. While in some circumstances they may encourage investment in poor neighborhoods and facilitate the functional economic integration between income groups, in others they may reinforce historic segregation patterns. The issue of scale seems paramount.

\section{Conclusion: Path dependency and the evolution of private urban governance}

We have reviewed the main converging lines of explanation for the spread of gated communities and more generally, privately governed neighborhoods. The conditions in contemporary metropolitan areas clearly play a role in the urban enclosure movement: fear of crime, political and fiscal fragmentation. GCs emerged as an innovation not only in real estate and urban design but in urban governance: designed fit the needs of residential demand for better lifestyle; designed to offset the burdens of inefficient public services; to exclude freeriders and unwanted 'others' by the means of gates and CC\&Rs. Their growth has been led strongly by supply-side innovations during periods of housing market boom and rapid urban expansion - in the US and in Asia, South America and Africa. These are classical Schumpetarian innovations - creatively destroying old notions about how cities should be governed.

We end the paper by advancing another argument: that the local institutional milieu - the nexus of laws and practices that shape local property markets, development industries and land regulations - create path dependencies in the local manifestation of the global trend towards private cities. They raise and lower the attractiveness of the private urban governance

35 model. They provide different local institutions against which the potentially destructive new institutions are sub-consciously and consciously assessed. For instance, the absence of gated communities in Germany is usually seen as resulting from the absence of legal structuring of horizontal residential co-ownership (Glasze 2003). In France, the existence of 36,600 municipalities (communes), most of them with 500-2000 inhabitants, does not favor the diffusion or invention of gated communities especially in the outer suburbs with an average population of 800 . Their municipal powers in regulating land use, zoning, and allocating resources are very strong and clearly favor social homogeneity of residential suburban schemes. In this context, suburban fragmentation is to be understood as a function of the institutional structure of French municipal government (Charmes 2005; 2007; 2009). There is less of an institutional gap at the neighborhood level than in most other European countries and less scope for the creative destruction of public urban governance models. Yet there is something of a paradox here. Gated communities in France are not a recent innovation. In 1978 a comprehensive survey found that there were 1,500 private neighbourhoods (villas) and private streets in the centre of Paris. In France, the 1804 Code civil sets up a condominium 

compass.com/subject/geography/article_view?article_id=geco_articles_bpl118].

law and regulates property rights, enclosures, rights of ways, contractual agreements and; subsequent laws on planned unit developments $(1923,1976,1986)$ derive from this legal framework : every new land subdivision in the country has been required by law to set up restrictive covenants and, in the case of private streets, a homeowners association. Streets can be either public (retrocession) or private. Under France's strong urban municipal culture, these have remained relatively under-used and minor elements of the overall urban governance infrastructure (much as town and parish councils have in the UK). In parts of the world where the state is not so successful at delivering civic goods and services or not so minded to do so, the borrowed and adapted French 1804 condominium idea has provided the legal basis for entrepreneurs to supply not just homes but entire neighborhoods complete with governance structures and private management (private versions of town halls for groups of anything from 200 to 200,000 residents). The largest gated community in the USA is Leisure World in California with about 19,500 people. The largest in the world is probably the suburban settlement in the Chinese city of Wuhan planned for 200,000 and built and governed 15 entirely by a for-profit company (Webster et al. 2006). Co-ownership institutions, such as the French Condominium law can, in principle, reproduce many of the features of politically organized municipal government. But that has apparently not been necessary in France, at least partly due to the scale and fiscal design of municipal government units.

20 It is perhaps surprising that the UK, with a relatively liberal modern political economy but strong tradition of municipal government and with its legacy of Ebenezer Howard's garden city idea (a late nineteenth-century precursor to the modern private community), has not been quicker to explore this new genre of urban living (Webster 2001). This may well change, however. Localization is a key political theme for all political parties in the UK at the moment 25 and there is a general acceptance of the need to innovate in neighborhood governance to tackle problems of urban regeneration. The connection has not generally be made with new development but there are signs that developers are exploring the possibilities of coownership institutions - as Britain's rapidly growing city centre condominium-style apartment boom illustrates. The U.K recently created its first commonhold tenure - in the

30 Commonhold and Leasehold Reform Act 2002 (Commencement Order) 2004. The point of the new law is to make the co-ownership and governance of shared facilities more efficient. It was conceived to solve the traditional problems of single buildings under leasehold tenure but it does much more than that: it opens up a new way of organizing collective action in urban neighbourhoods new and old. It competes with existing institutions such as community land 35 trust law, company law and leasehold law. A lack of well-founded legal structures has undoubtedly helped dampen interest in the various forms of private government in the UK (Webster, et al. 2005, Blandy 2006). China is currently grappling with the challenge of governance in its vast numbers of club communities. Home Owners Associations are not currently incorporated in law - shareholder run housing estates would create territorial democracy by the back door - and this limits their power and creates all manner of property rights ambiguities that municipal housing bureaus have stepped in to try and solve. China is a particularly good example of path dependency in the evolution of urban governance and gated and other club communities. It had a strong gating and enclave tradition in its historical cities. The legacy of the communist era was a strong collective consumption and production tradition - in terms of popular values and legacy institutions and organizations. Rapid urbanization, rising incomes and major land reform in the 1990s that suddenly created a property market led cities to expand largely by the development of gated compounds. The physical and organizational enclave form came first and the legal form is struggling problematically to catch 
Le Goix, R., \& Webster, C. (2008). Gated Communities. Geography Compass [http://www.blackwellcompass.com/subject/geography/article_view?article_id=geco_articles_bp/118].

up. Elsewhere in Asia, there are no such problems in drafting and re-drafting co-ownership laws. It is of interest to note that the lack of institutional framework did not prevent the development of privately governed neighborhoods in China. That was because the fiscal model and municipal political economy was a strong enough cause: all urban land is government owned and local governments derive most of their income from land sales (rather than property tax of transfers). Why would they lease land to a developer who did not offer to build, maintain and govern local neighborhood infrastructure?

The future of gated communities is not a singular one therefore. Each country, region and city has its own history: its own set of economic and political conditions; its own stock of built environment assets; its own property development industry. Nevertheless, certain trends are discernible, as we have discussed in this paper. Many of the more interesting research questions are about how these general patterns emerge from the locally particular contexts.

\section{References}

Altini G R and Akindele O A 2005 The effect that enclosing neighborhoods has on porperty values. International Symposium "Territory, Control and Enclosure", Pretoria, Rep. of South Africa, Feb 28-March 2, 2005

Atkinson R and Blandy S 2005 Introduction: International Perspectives on The New Enclavism and the Rise of Gated Communities. Housing Studies 20 (2) 177 - 186

Atlas R and Leblanc W G 1994 The impact on Crime of Streets Closures and Barricades: A Florida Case Study. Security Journal 5 140-145

Barzel Y 1997 Economic Analysis of Property Rights. Cambridge University Press, Cambridge, MA

Bible D S and Hsieh C 2001 Gated Communities and Residential Property Values. Appraisal Journal 69 (2) 140

Billard G Chevalier J and Madore F 2005 Ville fermée, ville surveillée : La sécurisation des espaces résidentiels en France et en Amérique du Nord Presses Universitaires de Rennes (coll. Géographie sociale), Rennes

Blakely E J and Snyder M G 1997 Fortress America, Gated Communities In The United States. Brookings Institution Press \& Lincoln Institute of Land Policy, Washington D.C., Cambridge, M.A.

Blandy S 2006 Gated communities in England: historical perspectives and current developments. GeoJournal 66 15-26

Blandy S Dixon J Dupuis A et al. 2006 The rise of private residential neighbourhoods in England and New Zealand in Glasze G Webster Cj and Frantz K eds Private Cities: Global and local perspectives Routledge, London 190-205

Blinnikov M Shanin A Sobolev N et al. 2006 Gated communities of the Moscow green belt: newly segregated landscapes and the suburban Russian environment. GeoJournal 66 65-81

Brower T 1992 Communities within the community: consent, constitutionalism, and other failures of legal theory in residential associations. Land Use and Environmental Law Journal 7 (2) 203273

Burke M 2001 The Pedestrian Behaviour of Residents in Gated Communities. Walking the 21st Century, Perth, Australia 139-150

Caldeira T P R 2000 City of Walls: Crime, Segregation, and Citizenship in Sao Paulo University of California Press, Berkeley, CA

Carvalho M Varkki George R and Anthony K H 1997 Residential Satisfaction in Condominios Exclusivos (Gate Guarded Neighborhoods) in Brazil. Environment and Behavior 29 (6) 734 768 
Le Goix, R., \& Webster, C. (2008). Gated Communities. Geography Compass [http://www.blackwellcompass.com/subject/geography/article_view?article_id=geco_articles_bp/118].

Charmes E 2005 La Vie périurbaine face à la menace des "gated communities" L'Harmattan, Paris Charmes E 2007 Suburban fragmentation versus mobilities : is suburbanism opposed to urbanism in Cybergeo (369) pp. [Online] http://www.cybergeo.eu/index4882.html

Charmes E 2009 (to be published) On the residential "Clubbisation" of the French Periurban Municipalities. Urban Studies

Chen C-Y and Webster C 2006 Privatising the governance and management of existing urban neighborhoods. Property Management 24 (2) 98-115

Chen S C and Webster C 2005 Homeowners Associations, Collective Action and the Costs of Private Governance. Housing Studies 20 (2) 205 - 220

10 Davis M 1990 City of Quartz, Excavating the Future of Los Angeles Verso (coll. The Haymarket Series), London

Dear M and Flusty S 1998 Postmodern urbanism. Annals of the Association of American geographers 88 (January 1998) 50-72

Degoutin S 2004 Petite histoire illustrée de la ville privée. Urbanisme (337)

15 Durington M 2006 Race, space and place in suburban Durban: an ethnographic assessment of gated community environments and residents. GeoJournal 66 147-160

Foldvary F 1994 Public Goods and Private Communities: the Market Provision of Social Services Edward Elgar, Aldershot

Fox-Gotham K 2000 Urban Space, Restrictive Covenants and the Origins of Racial Segregation in a US city, 1900-50. International Journal of Urban and Regional Research 24 (3) 616-633

Giroir G 2006 The Purple Jade Vilas (Beijing): a golden ghetto in red China in Glasze G Webster C and Frantz K eds Private Cities Gobal and Local Perspectives Routledge, London 142-152

Glasze G 2000 Les complexes résidentiels fermés au Liban. Observatoire de la Recherche sur Beyrouth (13) 6-11

25 Glasze G 2003 L'essor global des complexes résidentiels gardés atteint il l'Europe. Etudes Foncières (101) 8-13

Glasze G 2005 Some Reflections on the Economic and Political Organisation of Private Neighbourhoods. Housing Studies 20 (2) 221 - 233

Glasze G 2006 Segregation and seclusion: the case of compounds for western expatriates in Saudi Arabia. GeoJournal 66 83-88

Glasze G and Alkhayyal A 2002a Gated Housing Estates in the Arab World: Case Studies in Lebanon and Riyadh, Saudi Arabia. Environment and Planning B: Planning and Design 29 (3) $321-336$

Glasze G Frantz K and Webster C J 2002b The global spread of gated communities. Environment and Planning B: Planning and Design 29 (3) 315-320

Gordon T M 2004 Moving Up by Moving Out? Planned Developments and Residential Segregation in California. Urban Studies 41 (2) 441-461

Grant J 2005 Planning Responses to Gated Communities in Canada. Housing Studies 20 (2) 273 285

40 Hardin G 1968 The Tragedy of the Commons. Science 162 1243-1248

Helsley R W and Strange W C 1999 Gated Communities and the Economic Geography of Crime. Journal of Urban Economics (46) 80-105

Jackson K T 1985 Crabgrass Frontier; The Suburbanization of the United States. Oxford University Press, Oxford

Jürgens U and Landman K 2006 Gated communities in South Africa in Glasze G Webster Cj and Frantz K eds Private Cities: Global and local perspectives Routledge, Taylor and Francis, London 109-126

Kennedy D J 1995 Residential Associations as State Actors : Regulating the Impact of Gated Communities on Nonmembers. Yale Law Journal 105 (3) pp.761-793

50 Lacour-Little M and Malpezzi S 2001 Gated Communities and Property Values. Wells Fargo Home Mortgage and Department of Real Estate and Urban Land Economics - University of Wisconsin, Madison, WI $36 \mathrm{p}$.

Landman K 2006 Privatising public space in post-apartheid South African cities through neighbourhood enclosures. GeoJournal 66 133-146 
Le Goix, R., \& Webster, C. (2008). Gated Communities. Geography Compass [http://www.blackwellcompass.com/subject/geography/article_view?article_id=geco_articles_bp/118].

Le Goix R 2002 Les gated communities en Californie du Sud, un produit immobilier pas tout à fait comme les autres. L'Espace Géographique 31 (4) 328-344

Le Goix R 2003 Les gated communities aux Etats-Unis. Morceaux de villes ou territoires à part entière [Gated communities within the city in the US: Urban neighborhoods, or territories apart?]. PhD. Thesis, Department of Geography, Université Paris 1 Panthéon - Sorbonne

Le Goix R 2005 Gated Communities: Sprawl and Social Segregation in Southern California. Housing Studies 20 (2) 323 - 343

Le Goix R 2006 Gated communities as predators of public resources: the outcomes of fading boundaries between private management and public authorities in southern California in Glasze G Webster Cj and Frantz K eds Private Cities: Global and local perspectives Routledge, London 76-91

Le Goix R (2007) The impact of gated communities on property values: evidences of changes in real estate markets (Los Angeles, 1980-2000) in Cybergeo (375) pp. 20 p. [Online] Retrieved on 16 may $2007 \mathrm{http}: / / \mathrm{www} . c y b e r g e o . e u /$ index6225.html

Le Goix R and Webster C 2006 Gated communities, sustainable cities and a tragedy of the urban commons. Critical Planning 13 (summer 2006) 41-64 summer 2006

Leavitt J and Loukaitou-Sideris A 1994 Safe and Secure:Public Housing Residents in Los Angeles Define the Issues. Future and visions : Urban Public Housing : nov 1994, Cincinnati, Ohio, USA 287-303

Lee $\mathbf{S}$ and Webster C (2004) Urban rights and private communities in 2004 Informede Valladolid The right to security and safety $\mathrm{pp}$. [Online] http://www.ciudadderechos.org/english/pdf/aao.pdf

Lee S and Webster C 2006 Enclosure of the urban commons. GeoJournal 66 27-42

Lemanski C 2004 A new apartheid? The spatial implictions of fear of crime in Cape Town, South Afica. Envionment and Urbanization 16 (10) 101-112

Lentz S 2006 More gates, less community? Guarded housing in Russia in Glasze G Webster Cj and Frantz K eds Private Cities: Global and local perspectives Routledge, Taylor and Francis, London 206-221

Low S 2001 The Edge and the Center: Gated Communities and the Discourse of Urban Fear. American Anthropologist 103 (1) 45-58

Low S 2003 Behind the gates : life, security, and the pursuit of happiness in fortress America Routledge, New York

Low S (2006) Towards a Theory of Urban Fragmentation: A Cross-Cultural Analysis of Fear, Privatization, and the State in Cybergeo (349) pp. [Online] http://www.cybergeo.eu/index3207.html

Manzi T and Smith-Bowers B 2005 Gated Communities as Club Goods: Segregation or Social Cohesion? Housing Studies 20 (2) 345 - 359

Marcuse P 1997 The Ghetto of Exclusion and the Fortified Enclave: New Patterns in the United States. The American Behavioral Scientist (41) 311-326

McKenzie E 1994 Privatopia: Homeowner Associations and the Rise of Residential Private Government Yale University Press, New Haven (Conn.) ; London

McKenzie E 2003 Common interest housing in the communities of tomorrow. Housing Policy Debates 14 (1-2) 203-234

McKenzie E 2005 Constructing the Pomerium in Las Vegas: A Case Study of Emerging Trends in American Gated Communities. Housing Studies 20 187-203

McKenzie E 2006a Emerging trends in state regulation of private communities in the U.S. GeoJournal 66 89-102

McKenzie E 2006b The dynamics of privatopia: private residential governance in the USA in Glasze G Webster Cj and Frantz K eds Private Cities: Local and Global Perspectives Routledge, London

Newman 01972 Defensible Space: Crime prevention through Urban Design MacMillan, New York 
Le Goix, R., \& Webster, C. (2008). Gated Communities. Geography Compass [http://www.blackwellcompass.com/subject/geography/article_view?article_id=geco_articles_bp/118].

Newman O 1996 Creating Defensible Space. U.S. Department of Housing and Urban Development, Office of Policy Development and Research, Institute for Community Design Analysis, Center for Urban Policy Research, Rutgers University., Washington, D.C. 126 p.

Raposo R 2006 Gated communities, commodification and aestheticization: The case of the Lisbon metropolitan area. GeoJournal 66 43-56

Reville N and Wilson H (2000) Why We Oppose Gated Communities in Worcester. 2000 from: http://www/nindy.com/chw

Salcedo R and Torres A 2004 Gated Communities in Santiago: Wall or Frontier? International Journal of Urban and Regional Research 28 (1) 27-44

10 Sanchez T and Lang R E 2005 Security vs. Status? A First Lool at the Census' Gated Community Data. Journal od Planning Education and Research 24 (3) 281-291

Sorkin M 1992 Variations on a Theme Park: The New American City and the End of Public Space Hill and Wang, New York

Stoyanov P and Frantz K 2006 Gated communities in Bulgaria: interpreting a new trend in postcommunist urban development. GeoJournal 66 57-63

Thuillier G 2005 Gated Communities in the Metropolitan Area of Buenos Aires, Argentina: A challenge for Town Planning. Housing Studies 20 (2) 255 - 271

Tiebout C M 1956 A Pure Theory of Local Expenditures. Journal of Political Economy 64 (5) 416424

Vesselinov E Cazessus M and Falk W 2007 Gated communities and spatial inequality. Journal of Urban Affairs 29 (2) 109-127

Webster C 2007 Property rights, public space and urban design. Town Planning Review 78 (1) 81101

Webster C and Glasze G 2006a Dynamic urban order and the rise of residential clubs in Glasze G Webster C and Frantz K eds Private Cities: local and global perspectives Routledge, London 222-236

Webster C J 2001 Gated Cities of Tomorrow. Town Planning Review (72) 149-170

Webster C J 2002 Property Rights and the Public Realm: Gates, Green Belts, and Gemeinschaft. Environment and Planning B: Planning and Design 29 (3) 397-412

Webster C J 2003 The nature of the neighbourhood. Urban Studies 40 (13) 2591-2612

Webster C J and Lai L W C 2003 Property Rights, Planning and Markets: Managing Spontaneous Cities Edward Elgar, Chetlham, Glos

Webster C J and Le Goix R 2005 Planning by commonhold. Economic Affairs 25 (4) 19-23

Webster C J Wu F and Zhao Y 2006b China's modern walled cities. in Glasze G Webster Cj and Frantz K eds Private Cities: local and global perspectives Routledge, London 153-169

Wu F 2005 Rediscovering the 'Gate" Under Market Transition: From Work-unit Compounds to Commodity Housing Enclaves. Housing Studies 20 (2) 235 - 254 